\title{
PALAEOCLIMATIC RELICTS AND CLIMATIC DISJUNCTIONS IN THE FLORA OF NORTHERN PORTUGAL
}

\author{
João José Honrado ', Carlos Aguiar ${ }^{2}$, F. Barreto Caldas ', \\ Rubim Almeida da Silva ${ }^{1} \&$ Jorge Henrique CAPElo ${ }^{3}$
}

Abstract

Climate is generally considered the main factor determining the global distribution of plant and animal species.

Climate changes, depending on their rapidity and intensity, can give rise to events of (local, regional or global) extinction, redistribution of flora and fauna, population genetic divergence, ecotype diffe rentiation or even speciation. That is, climate changes reflect on both ecosystem structure and function, as well as on spatial organisation of the borders between biogeographic units, and eventually also on the genesis of both ecosystems and biogeographic units itself,

Specific physical conditions working at a local scale (microclimate), such as rocky cliffs, water courses or special types of rock, can enable the persistence of species in territories where the macroclimate is no longer appropriate for their occurrence. There are also those species whose taxonomic independence occurred under climate conditions which were very different from the current ones, and then became adapted to the plant communities developing under the new climate. If these species are common extant taxa elsewhere, they are called climatic disjunctions, but if their distribution is nowadays very restricted, they are known as climatic relicts.

A related concept is the one of "biogeographic relict". Traditionally, a biogeographic relict is an endemic taxon, with limited distribution range, descending of another taxon that was once widely distributed. Like many other concepts in Biogeography and Ecology, the concept of biogeographic relict depends on both space and time scales. Also, taxonomic entities of lower rank (the species and infraspecific ranks) are no more than useful abstractions, often very hard to relate to genetic distances. Therefore, we think it is possible to extend the concept of "relict" to the population level, at different biogeographic dimensions and time scales, as long as it is possible to relate current distribution patterns of those populations with specific palaeoclimatic periods and events. Within this wide concept of "relict", isolated populations of plants which are common in other biogeographic territories are here interpreted as climatic disjunctions. On the other hand, in order to keep the "taxon - biogeographic relict" concept, we think it is more appropriate, on a small spatial scale, to speak of relict populations of a given taxon, or then, of territorial (local) relict, as long as the specific biogeographic scale is referred.

Their specific survival conditions, the potential uniqueness of their genetic information, and the biogeographic significance of the plant communities they live in, give climatic relicts and disjunctions a remarkable conservation value. They are also precious sources of information concerning past climates.

In this paper, we present a preliminary list of palaeoclimatic relicts and climatic disjunctions of the Northern Portugal flora. We recognise three main types of relicts occurring in the territory: 1) Palaeoclimatic relicts (xerophytic and mesophytic subtypes); 2) Würmian temperate climatic disjunctions; and 3) Pre-würmian mediterranean climatic disjunctions. In this first approach, we only listed those taxa whose isolated populations are clearly related to specific palaeoclimatic periods and events. For each taxon, we present information on ecology and distribution in Portugal. We also address the conservation status of these relict populations and discuss future perspectives for their long-term preservation in the territory.

Key words: Flora, Northern Portugal, palaeoclimates, relict populations.

Resumo

Relíquias paleoclimáticas da flora do Norte de Portugal Continental - $O$ clima é unanimemente considerado o principal factor determinante da distribuição dos seres vivos à escala planetária.

As oscilações macroclimáticas, en função da sua rapidez e intensidade, poderão originar eventos de extinção (local, regional ou total), de redistribuição da flora e da fauna, de divergência genética interpopulacional, de diferenciação ecotípica ou mesmo de especiação. Consequentemente, as alterações macroclimáticas reflectem-se ao nivel da estrutura e da função dos ecossistemas e na disposição espacial das fronteiras entre unidades biogeográficas, quando não ao nível da própria génese dos ecossistemas e das unidades biogeográficas.

Determinadas condições físicas à escala local (microclimáticas) (e.g. escarpas rochosas, linhas de água, litologias particulares, etc.) podem possibilitar a persistência de espécies em territórios cujo macroclima se tornou entretanto desfavorável para elas (e.g. Notholaena marantae nas rochas ultrabásicas do Nordeste de Trás-os-Montes). Existem também exemplos de plantas (e.g. Ilex aquifolitum) que especiaram sob um macroclima muito distinto do actual e que se mostram adaptadas a comunidades vegetais actuais totalmente diferentes daquelas que as «viram nascen?. Se estas espécies são frequentes noutros territórios biogeográficos, as suas populações isoladas são conhecidas por «disjunções climáticas»; se, pelo contrário, são espécies com áreas de distribuição reduzidas, então são designadas por «relíquias paleoclimáticas».

1 Departamento de Botânica - Faculdade de Ciências \& UGEV-ICETA, Universidade do Porto (Portugal).

Escola Superior Agrária, Instituto Politécnico de Bragança (Portugal).

Estação Florestal Nacional. Instituto Nacional de Investigação Agrária, Lisboa (Portugal). 
Um conceito afim é o de «reliquia biogeográfica». Tradicionalmente, uma reliquia biogeográfica é um faxon endémico, com distribuição restrita, descendente de um outro taxon outrora amplamente distribuído. Como muitos outros conceitos em Biogeografia e Ecologia, o conceito de relíquia biogeográfica é sensivel às escalas espacial e temporal. Por outro lado, as categorias taxonómicas são simples abstraç̧ōes, sendo, frequentemente, as de nivel hierárquico inferior (espécie e categorias infra-específicas) dificeis de correlacionar com distâncias (dissimilaridades) genéticas. Por isso, somos da opinião de que é legítimo estender o cónceito de «reliquia» ao nivel da população, a espaços biogeográficos de diferente dimensão e categoria e a diferentes dimensōes temporais, quando os padrões da distribuição actual destas populações são correlacionáveis com determinados periodos e eventos paleoclimáticos. Nesta perspectiva alargada do conceito de "reliquia», as disjunções espaciais de plantas comuns noutros territórios biogeográficos são interpretáveis como disjunções climáticas. No entanto, mantendo como principio orientador o conceito de «taxon - reliquia biogeográfica», é, em nosso entender, mais apropriado, a uma escala espacial suficientemente pequena, falar em população reliquial de um taxon, ou então em reliquia territorial, desde que designando em concreto o espaço biogeográfico em análise.

As condições particulares de sobrevivência, a potencial singularidade da sua constituição genética e o significado biogeográfico que conferem às comunidades que integram atribuem às reliquias paleoclimáticas e disjunções climáticas um assinalável interesse para conservação. Constituem ainda preciosas fontes de informação sobre os bioclimas pretéritos.

No presente trabalho, é feita uma primeira aproximação à lista de reliquias paleoclimáticas e disjunções climáticas da flora do Norte de Portugal Continental.

Reconhecemos os seguintes tipos de reliquias territoriais no Norte de Portugal:

Tipo 1. Reliquias paleoclimáticas $(\mathrm{P})-$ Taxa característicos de vegetação paleotropical terciária, progressivamente substituida por vegetação mediterrânica e temperada a partir do Miocénico.

Subtipo 1.1. Xerofiticas (Px)-Entre este subgrupo de relíquias encontram-se fetos xerofiticos e gimnospérmicas aciculifólias.

subtipo 1.2. Mesofiticas (Pm)-Hoje em dia, na sua grande maioria, são fetos termo-higrófilos ou árvores e arbustos laurifólios.

Tipo 2. Disjunções climáticas temperadas würmianas $(\mathrm{T})$-espécies de óptimo biogeográfico eurosiberiano adaptadas ao macrobioclima temperado, andares supra a orotemperado, das quais sobreviveram pequenas populações acantonadas nas Serras mais elevadas do norte e centro de Portugal ou então a biótopos particularmente húmidos e sombrios, com o recuo dos gelos durante o Holocénico.

Tipo 3. Disjunções climáticas mediterrânicas ante-würmianas $(M)$ - espécies mediterrânicas, termófilas e por isso sensiveis aos frios invernais e frequentemente sem escamas de proteç̧ão (catáfilos) dos gomos vegetativos, reduzidas a pequenas populações nas áreas mais secas e quentes do vale do Douro. Supõe-se, e dai o seu carácter de reliquias territoriais, que a sua penetração neste vale tenha ocorrido antes da última glaciação. Esta hipótese só poderá ser definitivamente comprovada através de estudos filogeográficos.

Limitảmos a listagem das disjunções «temperadas würmianas» e «mediterrânicas ante-würmianas» àquelas que julgamos serem mais evidentes, pelo que, numa análise mais fina, o seu número poderá ser substancialmente incrementado. Em última análise, todas as pteridófitas (fetos e grupos afins) são relíquias paleoclimáticas; aqui, o critério foi, mais uma vez, seleccionar apenas as espécies cujos padrões de distribuição têm uma correlação mais nitida com periodos e eventos paleoclimáticos.

Neste trabalho é fornecida, para cada taxon, informação sobre a sua ecologia e a sua distribuição em Portugal, e, como já referido, é proposta uma tipologia para agrupar estes taxa em grupos com a mesma paleo-história. Finalmente, é referido o estado de conservação das populações destas plantas e são discutidas as perspectivas futuras de preservação no território considerado.

Palavras-chave: Flora, Norte de Portugal, paleoclimas, populações reliquiais.

\section{INTRODUCTION}

Climate is generally considered the main factor determining the global distribution of plants species, so that, in the absence of major antropic actions, vegetation in a specific biogeographic context (specially woody, non-hygrophilic, vegetation) mainly depends on macroclimate conditions. It is therefore understandable that Pleistocene macroclimatic oscillations produced such dramatic changes in the dis-tribution of plant species and communities (BENNET et al., 1991; FERris et al., 1993, 1995, 1998; MUÑoz et al., 1996; DUMOLIN-LAPÈGUE et al., 1997; COMES \& KADEREIT, 1998).

Recent data concerning Quaternary palaeoecology in Europe and North America have established the occurrence of southward contractions of distribution ranges of plant species, followed by rapid northward expansions at the end of each cold period. Within the Holarctic Kingdom, these migrations were more frequent and dramatic in mid-latitudes, although northern and southern territories may as well have been affected depending on the intensity of climate changes (RAVEN \& AXELROD, 1974; AXELROD, 1996; RAMIL- 
REgo et al., 1996). Phylogeographic studies (e.g. BENNET et al., 1991; FERRIS et al., 1993, 1995, 1998; DUMOLIN-LAPĖGUE et al., 1997) have repeatedly identified the southern peninsulas (Iberian, Italian and Balcanic) as major refuges for the flora during glacial periods.

The Pleistocene succession of cold and warm periods caused a significant redistribution of the coenozoic flora (MUÑOz et al., 1996; RAMIL-REGo et al., 1996). A large number of mesophilic and thermophilic species became extinct or confined, within Europe, to rather isolated positions in southern territories (mostly the current Mediterranean Region).

In spite of the severe climate conditions during Pleistocene glaciations, several kinds of evidence suggest that some forest remains could survive in topographically sheltered valleys of Western Iberian Peninsula (COUdÉ-GAUSSEN, 1981). The presence of these woodland environments, probably established on the exposed Continental Platform itself (DIAS et al., 1997) and in the deepest interior valleys, provided shelter for Tertiary relicts (the Artho-Tertiary subtropical flora), allowing the persistence of the isolated populations we can nowadays find in the flora of Northern Portugal.

After the last northward range expansion, many cold-tolerant species kept a few isolated populations in the southern refuges. In most cases, these assemblages are well out of their optimal situation under present climate conditions, and must therefore be regarded as climate-made disjunctions.

In this paper, we propose a classification system and present a preliminary list for palaeoclimatic relicts and climatic disjunctions in the flora of Northern Portugal.

\section{SOME GENERAL REMARKS ON THE BOTANICAL CONCEPT OF "RELICT"}

We now know from very diverse palaeoecological data sources that, depending on their rapidity and intensity, climate changes can give rise to events of i) local, regional or global extinction; ii) redistribution of flora and fauna; iii) population genetic divergence caused by genetic drift and migration; iv) ecotype (adaptive) differentiation; or even v) speciation. Effects of climate change on plant populations may also be indirect, through environmental changes promoting basically the same processes of biogeographic differentiation (e.g. changes in drainage regime of river basins, glacio-eustatic variations of coastal areas, etc.). Climatic processes have also acted in association with tectonic events in the past (e.g. the combined effects of Alpine orogeny and emergence of the mediterranean climate on the palaeomediterranean flora during Late Miocene). Climate changes reflect on ecosystem composition, structure and function, as well as on spatial organisation of the borders between biogeographic units, and eventually also on the genesis of both ecosystems and biogeographic units itself.

Specific physical conditions working at a local scale (microclimate), such as those that can be found in rocky cliffs, water courses or special types of rock, can, however, enable the persistence of species in territories where the macroclimate is no longer appropriate for their occurrence. If these species are common extant taxa elsewhere, they are called climatic disjunctions (PIELOU, 1992), but if their distribution is nowadays very restricted, they are known as climatic relicts (COX \& MOORE, 1993).

It is common to find, among recent climatic disjunctions, ecological shifts and inconsistent particular morphological traits, when comparing with the bulk of the species populations. There are even cases were it is already possible to attribute a taxonomic rank to these populations (e.g. genus Murbeckiella).

There are species whose taxonomic independence occurred under climate conditions - mostly tropical and subtropical ones - prevailing before the climatic shifts that took place by the end of the Miocene, and then became adapted to the plant communities developing under late-tertiary or quaternary climates: these species are testimonies of past environments and vegetation types now extinct or spatially very confined (e.g. subtropical laurel forests of Madeira). Iberian phytosociologists call this group of taxa palaeoclimatic relicts.

A related concept is the one of "biogeographic relict". Biogeographic relicts are narrowly distributed endemics, descendants of once widespread taxa (PIElou, 1992; Brown \& Lomolino, 1998), being palaeoclimatic relicts or not. For example, in Northern Portugal, possibly Murbeckiella sousae and M. grex boryi could be interpreted as biogeographic relicts in the sense of local narrow endemics derived from a once widespread (in this case, cold demanding) taxon. This could also be the case of Minuartia grex recurva, Teucrium salviastrum and Armeria grex humilis. However, the available information is for the moment insufficient.

There is an evident temporal and spatial scale differentiation between all these concepts, even though there can be some overlapping between them. Usually they are used at large space scales, often for high taxonomic ranks, but there is no reason why it should always be so. Within our studied territory, we interpret as small scale climatic disjunctions the isolated populations of species which are common in other, sometimes nearby, biogeographic territories, whose current distribution patterns are apparently correlated with specific palaeoclimatic periods and events. 


\section{A BRIEF SURVEY OF PALAEOCLIMATES AND RECENT} LANDSCAPE EVOLUTION IN NORTHERN PORTUGal

In North-western Iberia, two major floristic elements come together. On one hand, this territory is the south-westernmost area for eurosiberian temperate species; this element predominates in mountain areas and in lowland areas with high annual rainfall. The Mediterranean element, either reaching the territory from the western coast, or with a more continental origin from the Iberian "Meseta", predominates in lowland and mid-altitude areas with at least two dry months in summer. The present distribution of both floras is the consequence of physiography, antropic constraints and climatic evolution (RAMILREGO et al., 1995).

Pleistocene macroclimatic oscillations produced dramatic changes in the remaining Artho-Tertiary flora and vegetation of Western Iberian Peninsula. It is assumed that glaciers existed in the highest mountains of Northern Portugal during Pleistocene cold periods (cf. Coudé-GaUSSEN, 1981). The impacts of cold and dry climate conditions on vegetation included ecosystem destruction, vegetation altitudinal belt fluctuations, disruption and creation of migration routes, destruction or promotion of climatic disjunctions and relicts, and speciation by isolation or adaptive occupation of new habitats.

The last remains of tropical and subtropical Tertiary vegetation were eliminated from Northern Portugal by Pleistocene glaciations. During these cold and dry periods, dominant vegetation types would include oceanic steppe, continental steppe and boreal pine woodland, while temperate vegetation would be restricted to a few refuges in sheltered coastal and piedmont areas (MUNOZ et al., 1996). Also in these periods, the mediterranean flora migrated southwards, near the coast, or found refuge in the deepest warm valleys of Douro Basin. Predominant genera of woody plants in pleniglaciar ecosystems would include Pinus and Juniperus, nowadays confined to the highest mountains in the territory or to the deepest mediterranic interior valleys.

During the most recent interglacial or interstadial periods, mild temperatures and higher rainfall would have promoted both the expansion of temperate and mediterranean vegetation from refuge areas towards a domination, respectively, in mountains and lowland littoral or sub-littoral areas, and in the mediterranean areas of North-eastern Portugal.

Natural landscape evolution in Northern Portugal during the Holocene is assumed to have included: i) disappearance of Late Dryas steppe vegetation, establishment of Pinus-Betula mixed woodlands and the development of non-continental mediterranean vegetation (Pre-Boreal and Boreal periods); ii) expan- sion of Corylus and other oceanic elements in temperate areas (Boreal period); iii) expansion of temperate deciduous woodlands and restriction of boreal forests to the highest mountains (from the Atlantic period onwards).

Another important parameter influencing natural landscapes since the end of the last glaciation is human activity, mostly involving deforestation, animal grazing and, more recently, agriculture. The impact of these activities was most severe from the Atlantic period onward, with the advent of the Neolithic culture (MUÑOZ et al., 1996).

\section{The STUdY AREA: PRESENT LANDSCAPE AND BIO- geographic divisions in Northern Portugal}

This study was performed in the portuguese territories north of Douro River. There were two main reasons for selecting this large valley as our southern limit: i) for practical purposes, as it is an easily identifiable limit; and ii) we believe the Douro Valley was an important landscape element determining plant "migrations" and a shelter for thermophilic species during cold periods.

In terms of geomorphology, we can easily identify three main areas in the North of Portugal: i) the coast line and sub-coastal territories of Minho and Douro Litoral provinces; ii) a north-south oriented series of mountain ranges dividing the Northwest from the Northeast; and iii) the Northeast plateau of Trás-osMontes province, occasionally interrupted by smaller mountain ranges or deep north-south oriented valleys. The lithology is mainly made of acid rocks (granites and schists), with local outcrops of basic and ultrabasic rocks in eastern Trás-os-Montes.

The climate is very diverse. According to RivasMartínez's bioclimatic typology (RIVAS-MARTinez \& LOIDI, 1999), it ranges from Temperate Oceanic with Ultra-Per-Humid ombroclimate in the North-western mountains of Peneda and Gerês, to Mediterranean Pluviseasonal Oceanic with Dry ombroclimate or Mediterranean Xerophytic Oceanic with Semiarid ombroclimate in the deeper valleys of eastern Trás-osMontes. In terms of temperature regimes, we can distinguish: i) a highly oceanic climate in the coastal and subcoastal area, with temperate summers and mild winters; ii) temperate summers and cold winters in the central mountains; and iii) a rather continental climate in eastern Trás-os-Montes, with hot summers and cold winters.

The dramatic changes introduced by human activities on the vegetation cover, mostly since the Upper Neolithic period, as shown by palaeopalinological surveys in Northwest Iberia, have been particularly strong during the last 700 years, so that the character- 
istic woodland types are nowadays very hard to recognise. However, it seems reasonable to believe that, in the absence of antropic processes, primitive woodland types, as well as their distribution areas, would have been kept quite unchanged since the beginning of Lower Middle Age.

In spite of this important constraint, the approximate distribution of potential vegetation types in Northern Portugal was established by CosTA et al. (1998); this proposal has recently been revised by HonRado et al. (1999), AgUIAR (2001) and HonRADO (2001). Following the pattern described for the climate, climactic domains in Northern Portugal include woodland types dominated by four species of genus Quercus: Pedunculate Oak (Quercus robur) in the Northwest, Pyrenean Oak (Q. pyrenaica) in the extreme Northeast, and Cork Oak (Q. suber) and Holm Oak ( $Q$. rotundifolia) in the southern half of eastern Trás-os-Montes. Interestingly, in the areas of very low annual rainfall (bellow $c a .450 \mathrm{~mm}$ ) of South-eastern Trás-os-Montes, potential vegetation is not a woodland type, but mediterranean sclerophytic shrub formations.

Due to the introduction of antropic changes on natural potential vegetation, woodlands have been replaced by subseral communities, mostly shrubby formations. However, the "vegetation series" concept, relating all plant communities occurring, by means of natural succession, within an ecologically uniform area, allows us to infer potential distribution areas of woodland types from the distribution patterns of shrubby subseral formations, which in turn are quite faithful to biogeographic territories.

The biogeographic typology and natural potential vegetation types for Northern Portugal are illustrated in Figures 1 and 2, respectively.

\section{METhós}

The recognition of palaeoclimatic relicts and climatic disjunctions emerges from the wider scientific study of the portuguese flora and vegetation.

In the last two decades, a significant amount of floristic data has been collected as a parallel result of vegetation description according to Braun-Blanquet's sigmatist approach to phytosociology. This analytical system describes plant associations on the basis of a statistically recurrent combination of species, which in turn can be related to present types of vegetation. This approach has provided a powerful tool to address optimal and tolerance values of each species for key ecological parameters, such as those related to climate.

Based on our current knowledge of the flora of Northern Portugal, we tried to identify those taxa whose present population distribution pattern could be correlated to specific palaeoclimatic periods or events. For each taxon, we present information on its ecological preferences in Northern Portugal, its distribution area in Portugal and an estimate of its IUCN conservation status (AGUiAR et al., 1999).

Family names are those of Flora Iberica (CAstroviejo et al., 1986-1999).

\section{Results}

6.1 Types of palaeoclimatic relicts and climatic disjunctions in the flora of Northern Portugal

We recognise the following main types of relicts and disjunctions occurring in the territory:

Type I-Palaeoclimatic relicts

I.a. Xerophytic subtype

I.b. Mesophytic subtype

Type II - Würmian temperate climatic disjunctions

Type III - Pre-würmian mediterranean climatic disjunctions

\subsection{Palaeoclimatic relicts and climatic disjunc- tions in the flora of Northern Portugal}

In Tables I to IV, we present a preliminary list of palaeoclimatic relicts and climatic disjunctions of the Northern Portugal flora, with some general remarks on its main characters. For each taxon, we present information on ecology and distribution in Portugal. We also address the conservation status of the relict populations and discuss future perspectives for their long-term preservation in the territory.

In this first approach, we only listed climatic disjunctions whose isolated populations are clearly related to specific palaeoclimatic periods and events. All of them are plants with known and striking ecological needs that can be opposed to actual macroclimatic patterns.

\subsubsection{Palaeoclinatic relicts}

These are character species of Tertiary palaeotropical vegetation, which was gradually replaced by mediterranean and temperate vegetation during late Tertiary and Quaternary.

\subsubsection{Xerophytic palaeoclimatic relicts (Table I)}

This group includes xerophilic ferns and needlescale-leafed gymnosperms, thermo-hygrophilic ferns 
and lauriphyllous evergreen trees and shrubs. These palaeotropical elements are adapted to more continental, summer-dry areas than the mesophytic palaeoclimatic relicts.

\subsubsection{Mesophytic palaeoclimatic relicts (Table II)}

Mesophytic lauroid and lianoid palaeotropical relicts occupy the oceanic and rainy western territories. Today, most of these ferns and lauroid shrubs and trees are common in deciduous or semi-deciduous woodlands. It is possible that their survival during pleistocene glaciations depended on the presence of this kind of woodlands in sheltered positions of highly oceanic territories.

We believe that these woodland thermophilic elements had a major radiation event in the territory during the Atlantic period, under the Holocene climatic optimum with warm (ca. $2^{\circ} \mathrm{C}$ warmer than today) and rainy climate conditions.

Some of these species (e.g. Culcita macrocarpa, Vandenboschia speciosa, Woodwardia radicans) are considered differential elements of the Thermotemperate altitudinal belt in Northwest Iberian Peninsula (cf. Izco, 1988).

Another fine example of this kind of relict occurring just south of the study area (Aveiro district) is Rhododendron ponticum L. subsp. baeticum (Boiss. \& Reuter) Hand.-Mazz. (Ericaceae). Daphne laureola subsp. laureola (Thymelaeaceae), found in Sintra, and the ferns Asplenium hemionitis (Aspleniaceae) and Cheilanthes guanchica (Sinopteridaceae) are three other examples occurring in South-western Portugal.

\subsubsection{Wïrmian temperate climatic disjunc- tions (Table III)}

These are taxa with mostly eurosiberian distribution, adapted to temperate climates, which, after Pleistocene glaciations, became restricted to a few small populations in the highest mountains of North and Central Portugal.

Quaternary climate changes have also originated disjunct populations of these and other temperate species (e.g. Acer spp., Betula celtiberica, Corylus avellana, Fagus sylvatica) in the Mediterranean Region, occurring on soils with a superficial water table or in areas with heavy rainfall (e.g. North and Northwest facing slopes in mountains).

The species in this group are often the subject of phylogeographic studies in the European continent (e.g. BENNET et al., 1991; FERRIS et al., 1993, 1995, 1998; DeMESURE et al., 1996; DUMOLIN-LAPĖGUE et al., 1997).

\subsubsection{Pre-wiürmian mediterranean climatic disjunctions (Table IV)}

These are mediterranean, thermophilic taxa, sensible to winter temperatures and often with unprotected vegetative buds, which were reduced to small populations in the warmest and driest areas of the Douro valley.

We assume that their penetration in this valley occurred before the latest glaciation, hence their territorial relict character. We expect to confirm this hypothesis through molecular phylogeographic studies.

Another fine example of this kind of relict occurring just south of the study area is Flueggea tinctoria (L.) G.L. Webster (Euphorbiaceae).

\section{Discussion}

The flora of Northern Portugal includes ca. 40 taxa whose populations in the territory can be regarded as palaeoclimatic relicts or climatic disjunctions.

According to their palaeobiogeographic history, these taxa can be divided into four main types. Each one of these four groups is correlated with a specific palaeoclimatic event or period.

These taxa are a very important part of our botanical heritage. Their specific survival conditions (sheltered from an unfavourable mesoclimate), their history of continuous resilience against successive cold periods, the potential uniqueness of their genetic information and the biogeographic significance of the plant communities they live in give palaeoclimatic relicts and climatic disjunctions a remarkable conservation value. They are also precious sources of information concerning past climates and palaeoenvironments.

Future actions for their long-term preservation in the territory should include: i) the establishment of a critical list of relicts at a national level; ii) the collection of all kinds of information (ecological, palaeobotanical, chorologic) regarding these taxa; iii) the cartography of all national populations; iv) the assessment of intra- and inter-population genetic diversity; v) phylogeographic studies for selected $\operatorname{tax} a$; vi) the establishment of a conservation status at a national level; and vii) the implementation of taxonspecific conservation plans.

In this paper, we proposed a simple typological scheme for the classification of palaeoclimatic relicts and climatic disjunctions and presented our first contribution for a list of relict taxa in the flora of Northern Portugal. As we work on the following contributions, we expect that our effort can encourage similar studies for other areas of Portugal. 


\section{REFERENCES}

Agular, C. (2001) - Flora e Vegetação da Serra de Nogueira e do Parque Natural de Montesinho. Ph.D. Thesis. Instituto Superior de Agronomia, Lisboa. $661 \mathrm{pp}$.

Agular, C.; Honrado, J.J.; Sequeira, M.; Caldas, F.B.; Jansen, J.; Almeida da Silva, R.; Nepomuceno, H. \& SÉneCA, A. (1999) - "Plantas vasculares e briófitas raras e a proteger no Norte de Portugal Continental", V Jomadas de Taxonomia Vegetal, Lisboa.

Aguiar, C; Honrado, J.J. \& Almeida DA SILVA, R. (2000)"Vegetação florestal primitiva do Norte de Portugal Continental", 2as Jornadas do Quarernário (APEQ), Porto.

Alcoforado, M.I.; Alegria, M.F.; Pereira, A.R. \& Sirgado, C. (1982) - Dominios bioclimáticos em Portugal, definidos por comparaça dos indices de Gaussen e de Emberger: Centro de Estudos Geográficos (I.N.I.C.), Universidade de Lisboa. 27 pp.

AXELROD, D.I. (1996) - "Orjgin of deciduous and evergreen habits in temperate forests", Evolution, 20, p. 1-15.

BENNET, K.D;; TZEDAK1S, P.C. \& WILLIS, K.J. (1991) - "Quaternary refugia of north European trees", Joumal of Biogeography, 18 , p. 103-115.

Brown, J.H. \& Lomolino, M.V. (1998)-Biogeography. Sinauer Associates. Sunderland. $691 \mathrm{pp}$.

Castrovieio, S. et al. (1986-1999)-Flora Bberica-Plantas Vasculares de la Peninsula lberica e lskas Baleares, Vols. 1-7 (1), 8. Real Jardín Botánico, C.S.I.C., Madrid.

COMES, H.P. \& KADEREIT, I.W. (1998) - "The effect of Quatemary climatic changes on plant distribution and evolution", Trends in Plant Science, 3(11), p. 432-438.

Costa, J.C.; Agumar, C.; Capelo, J.h.; lousã, M. \& Neto, C. (1998) - "Biogeografía de Portugal Continental", Quercetea, 0, p $5-56$.

Coupd-Gnussen, G. (1981) - Les Serras da Peneda ef do Geres: $\dot{E}$ tude geomorphologique. Memórias do Centro de Estudos Geográficos, $n^{\circ}$ 5. I.N.I.C., Lisboa.

Cox, C. B. \& P. D. Moore (1993)-Biogeography: An ecological and Evolutionary Approach. Blackwell Science.

DAVEAU, S. (1977)-Répartition et withe des précipitations au Portugal. Memórias do Centro de Estudos Geográficos (I.N.I.C.), n' 3. Universidade de Lisboa. 192 pp. + mapas.

Demesure, B.; COMPS, B \& PETIT, R.J. (1996) - "Chloroplast DNA phylogeography of the common beech (Fagrs sylvatica L.) in Europe", Evolution, 50(6), p. 2515-2520.

DiAZ, J.A.; RonkIGUES, A. \& MAGALIHÃES, F. (1997) -- "Evolução da linha de costa, em Portugal, desde o último máximo glaciário até à actualidade", Estudos do Ouaternário, 1, p. 53-66.
Dumolin-Lapègue, S.; Demesure, B.; Fineschi, S; Le Corre, V. \& PETIT, R.J. (1997) - "Phylogeographic structure of white oaks throughout the European continent", Genetics, 146, p. 1475-1487.

Ferris, C.; OLIVER, R.P.; DAVY, A.J. \& HewITT, G.M. (1993) "Native oak chloroplasts reveal an ancient divide across Europe", Molecular Ecology, 2, p. 337-344.

Ferris, C.; Oluver, R.P.; Davy, A.J. \& Hewtrt, G.M. (1995) "Using chloroplast DNA to trace postglacial migration routes of oaks into Britain", Molecular Ecology, 4, p. 731-738.

FERrIS, C.; KING, R.A.; VÄINÖLÄ, R. \& HEWITT, G.M. (1998)"Chloroplast DNA recognizes three refugial sources of European oaks and suggests independent eastern and western immigrations to Finland", Heredity, 80, p. 584-593.

Honkado; J.J. (2001) - Clima e Vegetação: Conceilos gerais, Bioclimatologia e tipologias biogeográficas. Um exemplo no Noroeste de Portugal Continental. Departamento de Botanica, Faculdade de Ciências da Universidade do Porto.

Honrado, J.J.; Caldas, F.B.; Ortiz, S. \& Pulgak, I, (1999)"Aspectos geobotânicos do Parque Nacional da Peneda-Gerês", $2^{\circ}$ Encontro de Fitossociologia ALFA, Lisboa.

Izco, J. (1988) - "Caracterización florística del piso termocolino", Vol. Homenaje a P. Montserrat, p. 603-607. CSIC.

Martinez, A.; Ronkiguez, M.; Ramil-Rego, P. \& Monrez, C. (1995) - "Evolución morfogenética y edáfica durante el Tardiglaciar y el Holoceno en las sierras septentrionales de Galicia", Actas da $3^{\prime \prime}$ Remião do Quaternário Ibérico, p. 63-7!.

Muñoz, C.; Ramil-Rego, P; Gómez-Orellana, L. \& Rodriguez, M. (1996)-"Modificaciones del paisaje vegetal durante el Cuaternário en el NW de la Peninsula Ibérica: contextulización con las secuencias del SW de Europa", Férvedes, 3, p. 117-150.

Pielou, E.C. (1992) - Biogeography. Krieger Publishing Company, Malabar.

RAmil.-Rego, P.; MuÑoz, C.; Gómez-Orellana, L. \& Rodriguez, M. (1996) - "Cambios globales del clima y de los hábitats terrestres", Férvedes, 3, p. 9-31.

RAmil-Rego, P.; AIJA, M.J. \& Alonso, F. (1995) "Caracterización climática y vegetacional de la Serra de Gerês (Portugal) durante el Tardiglaciar y el Holoceno: análisis polínico de A Lagoa do Marinho", Actas da $3^{\prime \prime}$ Retmião do Quaternário Ibérico, p. 85-92.

RAVEN, P.H. \& AxELROD, D.I. (1974) - “Angiosperm biogeography and past continental movements", Ann. Missotwi Bot. Gard, 61, p. $539-673$.

Rivas-Martinez, S. \& Loidi, J. (1999) - "Bioclimatology of the Iberian Peninsula", Itinera Geobotanica, 13, p. 41-47. 

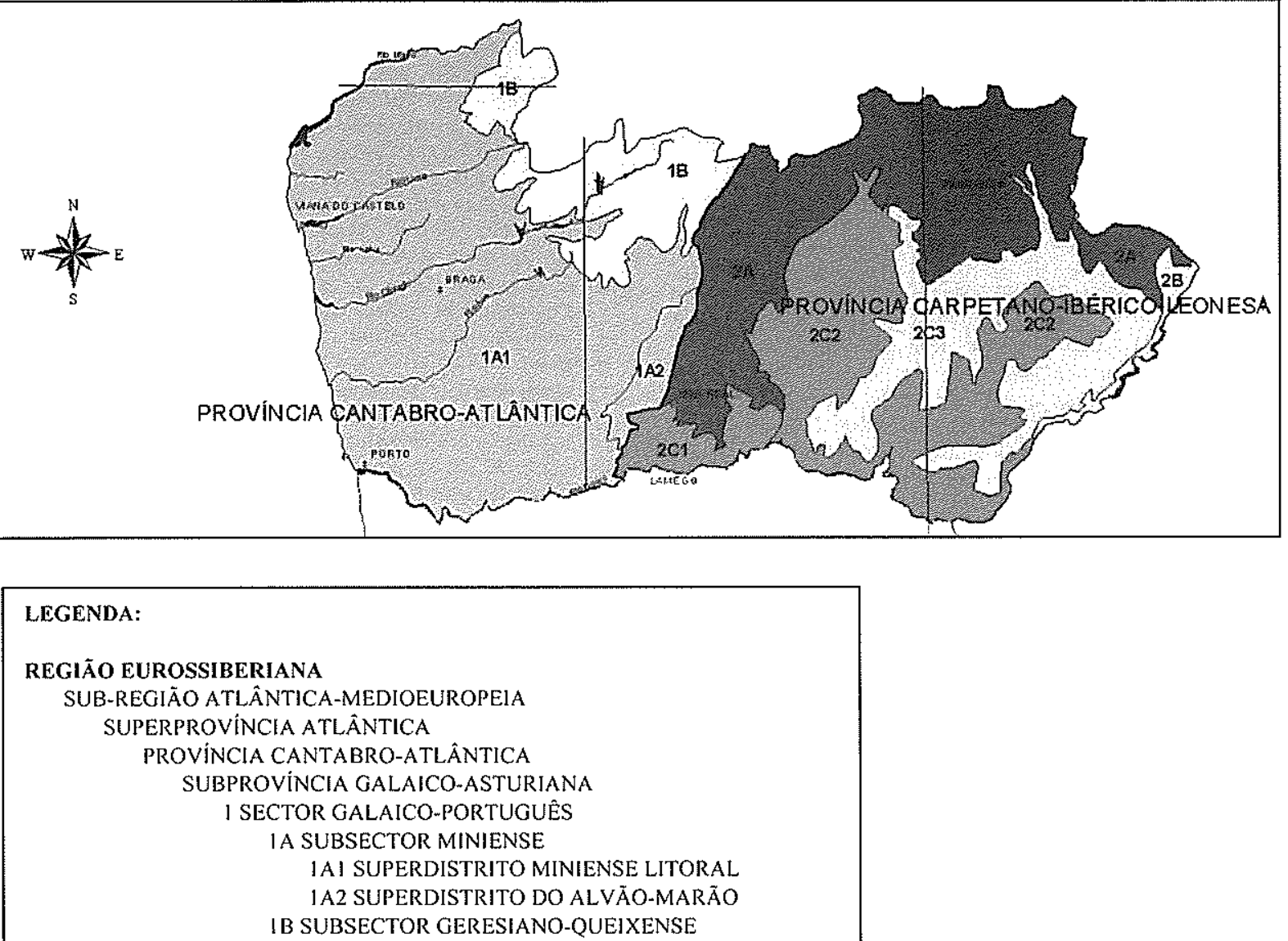

LEGENDA:

REGIÃO EUROSSIBERIANA

SUB-REGIÄO ATLÂNTICA-MEDIOEUROPEIA

SUPERPROVÍNCIA ATLÂNTICA

PROVINCIA CANTABRO-ATLÂNTICA

SUBPROVINCIA GALAICO-ASTURIANA

I SECTOR GALAICO-PORTUGUÊS

IA SUBSECTOR MINIENSE

1AI SUPERDISTRITO MINIENSE LITORAL

1A2 SUPERDISTRITO DO ALVÃO-MARÃO

IB SUBSECTOR GERESIANO-QUEIXENSE

\section{REGIĀO MEDITERRÂNICA}

SUB-REGIÃO MEDITERRÂNICA OCIDENTAL

SUPERPROVINCIA MEDITERRÂNICA IBERO-ATLÂNTICA

PROVÍNCIA CARPETANO-IBÉRICO-LEONESA

2A SECTOR ORENSANO-SANABRIENSE

2B SECTOR SALMANTINO

2C SECTOR LUSITANO-DURIENSE

$2 \mathrm{C} 1$ SUPERDISTRITO DURIENSE

2C2 SUPERDISTRITO DA TERRA QUENTE

2C3 SUPERDISTRITO DE MIRANDA-BORNES-ANSIÃES

Fig. 1 - Biogeographic divisions in Northern Portugal (modified from CosTA et al., 1998),

Fig. 1 - Tipologia biogeográfica do Norte de Portugal (modificado de CosTA et al., 1998).

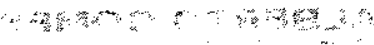




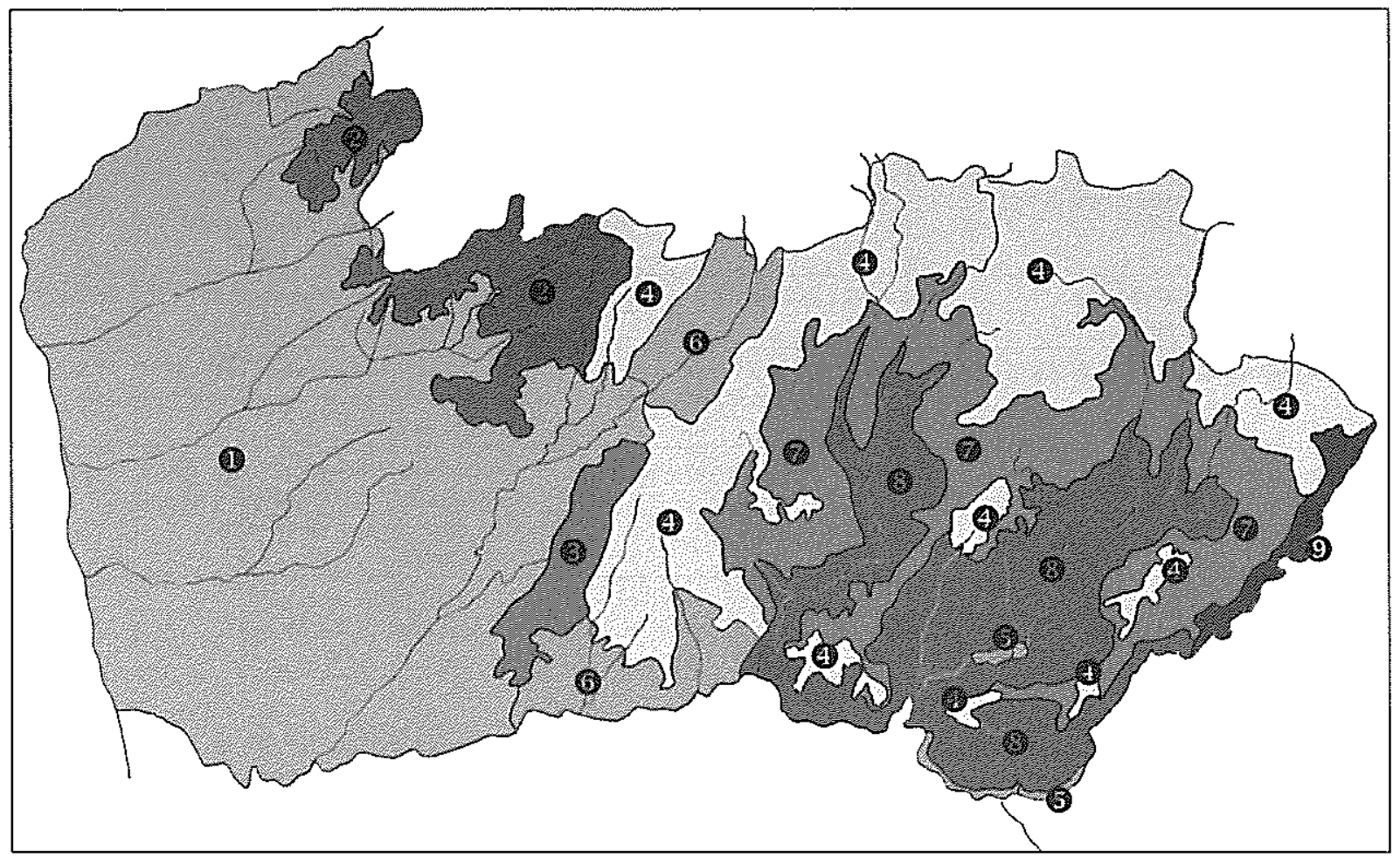

1 Bosques temófilos de carvalho-alvarinho (Quercus robur) da Rusco aculeati-Quercetum roboris

2 Bosques orófilos de carvalho-alvarinho (Quercus robur) da Myrtillo-Quercetum roboris

3 Rusco aculeati-Quercetum roboris e Myrtillo-Quercetum roboris

4 Bosques de carvalho-negral (Quercus pyrenaica) da Holco molis-Quercetum pyrenaicae

5 Matagais de zimbro (Jumiperus oxycedrus), oliveira-brava (Olea europaea var. sylvestris), comalheira (Pistacia terebinthus), azjnheira (Quercus rotundifolia) e (Rhamnus lyciodes subsp. oleoides da Asparago albi-Rhamnion alaterni

6 Bosques de sobreiro (Quercus suber) da Physospermo Quercetum suberis subas. quercetosum suberis

7 Bosques de sobreiro (Quercus suber) e carvalho-cerquinho (Q. faginea subsp. faginea) da Physospermo comubiensis-Quercetum suberis subas. quercetosum fagineae

8 Bosques de sobreiro (Quercus suber), carvalho-cerquinho ( $Q$. fagineae subsp. faginea) e zimbro (Juniperus oxycedrus) da Junipero oxycedri-Quercetum suberis

9 Bosques de azinheira (Quercus rotundifolia) e zimbro (Juniperus oxycedrus) com Genista hystrix da Junipero oxycedri-Quercetum rotundifoliae subas. pistacietosum terebinthi

Fig. 2 - Natural potential vegetation types in Northern Portugal, according to AGUiAR et al., (2000).

Fig. 2 - Tipos de vegetação potencial natural no Norte de Portugal, segundo Aciviar et al., (2000). 
Table I - Xerophytic palaeoclimatic relicts in the flora of Northern Portugal.

Tabela I-Relíquias paleoclimáticas xerofíticas da flora do Norte de Portugal.

\begin{tabular}{|c|c|c|c|}
\hline Taxon & Ecology in Northern Portugal & Distribution in Portugal & $\begin{array}{l}\text { IUCN } \\
\text { status }\end{array}$ \\
\hline $\begin{array}{l}\text { Cheilanthes maderensis Lowe } \\
\text { (SINOPTERIDACEAE) }\end{array}$ & Rock crevices. & $\begin{array}{l}\text { Warmest areas of the Douro valley, } \\
\text { International course of Tagus river, } \\
\text { mountains of Southwest Portugal. }\end{array}$ & $\mathrm{LR}(\mathrm{nt})$ \\
\hline $\begin{array}{l}\text { Cosentinia vellea (Aiton) Tod. } \\
\text { (HEMIONITIDACEAE) }\end{array}$ & Rock crevices. & $\begin{array}{l}\text { Barca d'Alva, Arrábida mountain } \\
\text { range, Guadiana valley and Algarve. }\end{array}$ & $\mathrm{LR}(\mathrm{nt})$ \\
\hline Juniperus oxycedrus L. (CUPRESSACEAE) & $\begin{array}{l}\text { Holm Oak and Cork Oak } \\
\text { xerophytic woodlands; rocky } \\
\text { outcrops. }\end{array}$ & $\begin{array}{l}\text { Tagus valley, driest areas of Trás-os- } \\
\text { Montes e Alto Douro province and } \\
\text { Campina da Idanha. }\end{array}$ & LR(lc) \\
\hline $\begin{array}{l}\text { Juniperts turbinata Guss. } \\
\text { (CUPRESSACEAE) }\end{array}$ & $\begin{array}{l}\text { Dunes; particularly dry and hot } \\
\text { valleys. }\end{array}$ & $\begin{array}{l}\text { Coastal areas south of the Vouga } \\
\text { river, Guadiana valley and Barrocal } \\
\text { Algarvio. Recently extinct in the } \\
\text { Douro valley. }\end{array}$ & $\operatorname{LR}(\mathrm{lc})$ \\
\hline $\begin{array}{l}\text { Notholaena marantae (L.) Desv. } \\
\text { (SINOPTERIDACEAE) }\end{array}$ & $\begin{array}{l}\text { Ultra-basic rocks of Northeastern } \\
\text { Portugal; one population on acid } \\
\text { rocks in the Sabor valley. }\end{array}$ & $\begin{array}{l}\text { Polimmetamorphic outcrops of } \\
\text { Bragança-Vinhais and Morais. }\end{array}$ & VU \\
\hline
\end{tabular}

Table II - Mesophytic palaeoclimatic relicts in the flora of Northern Portugal.
Tabela II - Relíquias paleoclimáticas mesofiticas da flora do Norte de Portugal.

\begin{tabular}{|c|c|c|c|}
\hline Taxon & Ecology in Northern Portugal & Distribution in Portugal & $\begin{array}{l}\text { IUCN } \\
\text { status }\end{array}$ \\
\hline Arbutus anedo L. (ERICACEAE) & $\begin{array}{l}\text { Evergreen woodlands, } \\
\text { thermoplilic oak woodlands and } \\
\text { relict arbutus groves. }\end{array}$ & Scattered throughout the country. & $\mathrm{LR}(\mathrm{lc})$ \\
\hline Buxus sempervirens L. (BUXACEAE) & $\begin{array}{l}\text { Rocky outcrops in llooding } \\
\text { margins of rivers. }\end{array}$ & $\begin{array}{l}\text { Sabor river and main tributaries. } \\
\text { Locally in the Tua and Douro rivers } \\
\text { valleys. Very rare in the limestone } \\
\text { outcrop of Estremadura. }\end{array}$ & LR(11t) \\
\hline $\begin{array}{l}\text { Culcita macrocarpa C. Presl } \\
\text { (DAVALLIACEAE) }\end{array}$ & $\begin{array}{l}\text { Shaded vertical walls of ancient } \\
\text { Roman gold mines. }\end{array}$ & $\begin{array}{l}\text { Vertical walls of ancient Roman gold } \\
\text { mines in Santa Justa and Pias } \\
\text { mountains (Valongo). }\end{array}$ & EN \\
\hline $\begin{array}{l}\text { Davallia canariensis (L.) Sm. } \\
\text { (HYMENOPHYLLACEAE) }\end{array}$ & $\begin{array}{l}\text { Epiphyte on Pedunculate Oak } \\
\text { trees; crevices of granite } \\
\text { outcrops. }\end{array}$ & $\begin{array}{l}\text { Locally in western provinces of North } \\
\text { and Central Portugal. }\end{array}$ & $\mathrm{LR}(\mathrm{nt})$ \\
\hline Ilex aquifolium L. (AQUIFOLIACEAE) & Deciduous woodlands. & $\begin{array}{l}\text { Northwest, Sintra mountain and } \\
\text { highest mountain ranges of North and } \\
\text { Central Portugal; very rare in the } \\
\text { Southwest. }\end{array}$ & $\mathrm{LR}(\mathrm{lc})$ \\
\hline $\begin{array}{l}\text { Lycopodiella cernua (L.) Pichi Serm. } \\
\text { (LYCOPODIACEAE) }\end{array}$ & Shaded and humid places. & $\begin{array}{l}\text { One known population in Santa Justa } \\
\text { mountain (Valongo), the only one in } \\
\text { the European Continent. }\end{array}$ & $\mathrm{CR}$ \\
\hline $\begin{array}{l}\text { Prumus lusitanica L. subsp. lusitanica } \\
\text { (ROSACEAE) }\end{array}$ & $\begin{array}{l}\text { Humid places within oak } \\
\text { woodlands and arbutus groves, } \\
\text { dominant in gallery formations in } \\
\text { areas with high rainfall and } \\
\text { frequent fog. }\end{array}$ & Locally in North and Central Portugal. & $\mathrm{LR}(\mathrm{lc})$ \\
\hline Taxus baccata L. (TAXACEAE) & $\begin{array}{l}\text { Deciduous woodlands and } \\
\text { mountain scrub. }\end{array}$ & $\begin{array}{l}\text { Estrela and Gerês mountain ranges. } \\
\text { Extinct in Montesinho mountain } \\
\text { range. }\end{array}$ & LR(lc) \\
\hline $\begin{array}{l}\text { Vandenboschia speciosa (Willd.) Kunkel } \\
\text { (HYMENOPHYLLACEAE) }\end{array}$ & $\begin{array}{l}\text { Shaded vertical walls of ancient } \\
\text { Roman gold mines. }\end{array}$ & $\begin{array}{l}\text { One population on vertical walls of } \\
\text { ancient Roman gold mines in Santa } \\
\text { Justa mountain (Valongo). }\end{array}$ & $\mathrm{CR}$ \\
\hline $\begin{array}{l}\text { Woodwardia radicans (L.) Sm. } \\
\text { (BLECHNACEAE) }\end{array}$ & $\begin{array}{l}\text { Rocky slopes in riparian and } \\
\text { other shaded woodlands. }\end{array}$ & $\begin{array}{l}\text { Western piedmont of Gerês mountain } \\
\text { range; valley of Trovela river (Ponte } \\
\text { de Lima). }\end{array}$ & VU \\
\hline
\end{tabular}


Table III - Würmian temperate climatic disjunctions in the flora of Northern Portugal.
Tabela III - Disjunções climáticas temperadas würmianas da flora do Norte de Portugal.

\begin{tabular}{|c|c|c|c|}
\hline Taxon & Ecology in Northern Portugal & Distribution in Portugal & $\begin{array}{l}\text { IUCN } \\
\text { states }\end{array}$ \\
\hline Allium victorialis $\mathrm{L}$. (LILIACEAE) & $\begin{array}{l}\text { Tall herb communities of humid } \\
\text { depressions in Pyreneen Oak } \\
\text { woodlands and birch formations. }\end{array}$ & $\begin{array}{l}\text { Gerês, Estrela and Nogueira mountain } \\
\text { ranges. }\end{array}$ & $\mathrm{LR}(\mathrm{nt})$ \\
\hline Amelanchier ovalis Medicus (ROSACEAE) & $\begin{array}{l}\text { Rocky places, flooding margins, } \\
\text { and woodland clearings in } \\
\text { mountain areas. }\end{array}$ & $\begin{array}{l}\text { Gerês and Nogueira mountain ranges; } \\
\text { flooding margins of the upper course } \\
\text { of Tuela and Sabor rivers. }\end{array}$ & $\mathrm{LR}(\mathrm{lc})$ \\
\hline $\begin{array}{l}\text { Epilobium anglustifolium } \mathrm{L} \text {. } \\
\text { (ONAGRACEAE) }\end{array}$ & $\begin{array}{l}\text { Sub-nitrophilic tall herb } \\
\text { communities in cleared or burnt } \\
\text { woodland areas. }\end{array}$ & $\begin{array}{l}\text { Gerês and Montesinho mountain } \\
\text { ranges. }\end{array}$ & Vu \\
\hline $\begin{array}{l}\text { Jimiperus communis L. subsp. alpina (Suter) } \\
\text { Celak. (CUPRESSACEAE) }\end{array}$ & $\begin{array}{l}\text { Climactic mixed woodlands and } \\
\text { climactic or subseral scrub, in } \\
\text { silicious oro-temperate and supra- } \\
\text { temperate territories. }\end{array}$ & Gerês and Estrela mountain ranges. & EN \\
\hline $\begin{array}{l}\text { Menyanthes trifoliata } \mathrm{L} \text {. } \\
\text { (MENYANTHACEAE) }\end{array}$ & $\begin{array}{l}\text { Shallow lagoons within bog } \\
\text { systems in mountain areas. }\end{array}$ & $\begin{array}{l}\text { Mourela plateau (Barroso) and Estrela } \\
\text { mountain range. }\end{array}$ & $\mathrm{EN}$ \\
\hline $\begin{array}{l}\text { Murbeckiella boryi (Boiss.) Rothm. } \\
\text { (CRUCIFERAE) }\end{array}$ & $\begin{array}{l}\text { Narrow crevices of granite } \\
\text { outcrops. }\end{array}$ & $\begin{array}{l}\text { Gerês, Marão and Estrela mountain } \\
\text { ranges. }\end{array}$ & LR(nt) \\
\hline $\begin{array}{l}\text { Pinguicula vulgaris L. } \\
\text { (LENTIBULARIACEAE) }\end{array}$ & Peaty soils in mountain areas. & Gerês mountain range. & EN \\
\hline $\begin{array}{l}\text { Pimis sylvestris L. (PINACEAE) } \\
\text { (autochtonous trees) }\end{array}$ & $\begin{array}{l}\text { Relict woodlands of temperate } \\
\text { mountain areas. }\end{array}$ & $\begin{array}{l}\text { Two populations in the eastern areas } \\
\text { of Gerês mountain range. }\end{array}$ & EN \\
\hline $\begin{array}{l}\text { Pritzelago alpina (L.) Kuntz subsp. } \\
\text { anerswaldi (Willk.) Greuter \& Burdet } \\
\text { (CRUCIFERAE) }\end{array}$ & $\begin{array}{l}\text { Humid rocks seasonally covered } \\
\text { by slowly running base-rich } \\
\text { water. }\end{array}$ & $\begin{array}{l}\text { Two populations in the valleys of } \\
\text { Tuela and Rabaçal rivers. }\end{array}$ & EN \\
\hline $\begin{array}{l}\text { Rumex longifolits DC. } \\
\text { (POLYGONACEAE) }\end{array}$ & $\begin{array}{l}\text { Semi-natural nitrophilic } \\
\text { grasslands. }\end{array}$ & $\begin{array}{l}\text { One poptlation in Montesinho } \\
\text { mountain range. }\end{array}$ & $\mathrm{CR}$ \\
\hline Salix caprea L. (SALICACEAE) & Riparian woodlands. & $\begin{array}{l}\text { One population in the limestone area } \\
\text { of Estremadura; recently extict in } \\
\text { Montesinho mountain range. }\end{array}$ & $\mathrm{CR}$ \\
\hline Solix repens L. (SALICACEAE) & Mountain bog systems. & Gerês and Larouco mountain ranges. & EN \\
\hline Sorbus aria (L.) Crantz (ROSACEAE) & Mixed deciduous woodlands. & Gerês and Estrela mountain ranges. & LR(nt) \\
\hline Sorbus torminalis (L.) Crantz (ROSACEAE) & Mixed deciduous woodlands. & $\begin{array}{l}\text { Gerês, Nogueira and Estrela mountain } \\
\text { ranges. }\end{array}$ & VU \\
\hline
\end{tabular}


Table IV - Pre-würmian mediterranean climatic disjunctions in the flora of Northern Portugal.
Tabela IV - Disjunções climáticas mediterrânicas ante-würmianas da flora do Norte de Portugal.

\begin{tabular}{|c|c|c|c|}
\hline Taxon & Ecology in Northern Portugal & Distribution in Portugal & $\begin{array}{l}\text { IUCN } \\
\text { status }\end{array}$ \\
\hline Allizm roseum L. (LILIACEAE) & Woodland clearings and scrub. & $\begin{array}{l}\text { Deepest parts of Douro and Sabor } \\
\text { river valleys; Southern Portugal. }\end{array}$ & $\mathrm{LR}(\mathrm{lc})$ \\
\hline Asparaguss albus L. (LILIACEAE) & Xero-thermophilic scrub. & $\begin{array}{l}\text { Deepest parts of Douro and Sabor } \\
\text { river valleys and their main } \\
\text { tributaries; Southern Portugal. }\end{array}$ & $\mathrm{LR}(\mathrm{lc})$ \\
\hline Asparagus aphy/hus L. (LILIACEAE) & Xero-thermophilic scrub. & $\begin{array}{l}\text { Deepest parts of Douro and Sabor } \\
\text { river valleys and their main } \\
\text { tributaries; Western coast; Southern } \\
\text { Portugal. }\end{array}$ & $\operatorname{LR}(\mathrm{lc})$ \\
\hline $\begin{array}{l}\text { Convolvulus siculus L. } \\
\text { (CONVOLVULACEAE) }\end{array}$ & Woodland clearings and scrub. & $\begin{array}{l}\text { Barca D'Alva, International course of } \\
\text { Tejo River, Mértola and Algarve. }\end{array}$ & $\operatorname{LR}(\mid c)$ \\
\hline $\begin{array}{l}\text { Olea europaea L. var. sylvestris (Mill.) Lehr. } \\
\text { (OLEACEAE) }\end{array}$ & Xero-thermophilic scrub. & $\begin{array}{l}\text { Deepest parts of Douro and Sabor } \\
\text { river valleys and their tributaries; } \\
\text { Southern Portugal. }\end{array}$ & $L R(l c)$ \\
\hline Ononis natrix L (LEGUMINOSAE) & $\begin{array}{l}\text { Sandy river margins and coastal } \\
\text { dunes. }\end{array}$ & $\begin{array}{l}\text { Deepest parts of Douro and Sabor } \\
\text { river valleys; Central and Southern } \\
\text { coastal areas. }\end{array}$ & LR(Ic) \\
\hline Phillyrea media L. (OLEACEAE) & Xero-thermophilic scrub. & $\begin{array}{l}\text { Deepest parts of Douro and Sabor } \\
\text { river valleys; Southern Portugal. }\end{array}$ & $\mathrm{LR}(\mathrm{lc})$ \\
\hline $\begin{array}{l}\text { Plantago albicans L. } \\
\text { (PLANTAGINACEAE) }\end{array}$ & Sandy river margins. & $\begin{array}{l}\text { Barca d'Alva; eastern Alentejo and } \\
\text { Algarve. }\end{array}$ & LR(lc) \\
\hline $\begin{array}{l}\text { Rhamnus lycioides L. subsp. oleoides (L.) } \\
\text { Jahandiez \& Maire (RHAMNACEAE) }\end{array}$ & Xero-thermophilic scrub. & $\begin{array}{l}\text { Deepest parts of Douro and Sabor } \\
\text { river valleys and their main } \\
\text { tributaries; Southeastern Portugal. }\end{array}$ & LR(lc) \\
\hline
\end{tabular}

